\title{
Assessment of Deciduous Dentition in 6-10 Year Old School Children
}

\author{
Svjetlana Janković ${ }^{1}$, Bojana Davidović ${ }^{1}$, Mirjana Ivanović ${ }^{2}$, Jelena Lečić ${ }^{3}$, Slavoljub Tomić ${ }^{4}$ \\ ${ }^{1}$ Department of Preventive Dentistry and Pedodontics, Study Program of Dentistry, Faculty of Medicine, \\ University of East Sarajevo, Foča, Bosnia and Herzegovina; \\ ${ }^{2}$ Department of Preventive Dentistry and Pedodontics, Faculty of Dental Medicine, University of Belgrade, Belgrade, \\ Serbia; \\ ${ }^{3}$ Department of Periodontology and Oral Medicine, Study Program of Dentistry, Faculty of Medicine, \\ University of East Sarajevo, Foča, Bosnia and Herzegovina; \\ ${ }^{4}$ Department of Oral Surgery, Study Program of Dentistry, Faculty of Medicine, University of East Sarajevo, Foča, \\ Bosnia and Herzegovina
}

\begin{abstract}
SUMMARY
Introduction The emergence of deciduous teeth in the mouth of a child usually brings a joy to every parent. However, after "short-time euphoria" deciduous teeth, in most cases, become the cause of pain, swelling, infection and further complications. The aim of this study was to assess the status of deciduous teeth in school children.

Material and Methods The study included children age 6-10 years from four cities in Republika Srpska. All respondents were divided in two groups: Group I included those who voluntarily came to be examined at the dental clinic and the Group II-those who were randomly chosen in schools. The examination was performed using dental mirror and probe. Caries verification was carried out by Klein-Palmer system, $\mathrm{dmft}$ ( $\mathrm{d}$ - decay; $\mathrm{m}$ - missing; $\mathrm{f}$ - filling), and its related indices: Person caries index (pci) and Average caries index (aci). In addition, a survey was conducted.

Results A total number of 228 respondents were examined. Total pci was $96.1 \%$. On average, each child had aci $=4.17$ while $10.52 \%$ of the children had fillings in primary teeth. None of the children had sealed fissures on deciduous teeth. Physical examination revealed that $12.2 \%$ of the children had submucous abscess in oral cavity. The survey revealed that $3 \%$ of children did not have a tooth brush.

Conclusion The prevalence of caries in primary teeth is high, despite the fact that the Health Insurance Fund in Republika Srpska covers full cost for complete restoration of teeth in children up to 15 years old. Responsibility for the low percentage of healthy and filled teeth is relying mostly on parents as well as the entire community that should provide development and availability of public health dental care in all areas.
\end{abstract}

Keywords: deciduous teeth; caries; dmft; children

\section{INTRODUCTION}

Deciduous teeth (dentes lactales, dentes decidua, dentes caduci) differ from permanent teeth by morphological and histological characteristics. Of the morphological characteristics, the most pronounced differences are in number, shape, size and color of teeth. A special feature is the existence of enamel-dentin ridge located on the vestibular surface of molars, which protects gingiva from food impaction. Deciduous teeth are smaller than permanent, enamel rarely exceed an average thickness of $1 \mathrm{~mm}$. Due to poorer mineralization, tooth color is milky-white while cutting edge often shows attrition [1]. Of histological features, the most pronounced changes are in teeth mineralization. The part of enamel synthesized before birth shows better mineralization. The number of tubules is smaller but wider and irregular in shape. Cement is thin and poorly mineralized while pulp chamber is voluminous with prominent horns. Sharpey's fibers are irregular and their number is lower than in permanent teeth [1].

The first deciduous tooth erupts usually at age 6-8 months, while complete deciduous dentition is formed around age 3. With the eruption of teeth, there is a change in oral microflora, and microorganisms that primarily live on teeth appear (Streptococcus sanguis, Streptococcus mutans and Actinomyces viscosus) [2]. Today, tooth decay is the most prevalent chronic disease in children [3]. Due to the frequency and distribution of tooth decay it has become a public health problem [4]. New findings in the field of biochemistry, microbiology, scanning electron microscopy and other sciences, have led to the current view that caries is an infectious disease, directly dependent on diet [5].

Most of studies and national surveys carried out in different geographical areas and different countries about the prevalence of caries have been focused on children age 6,12 and 15. However, data about the status of teeth in

Address for correspondence: Svetlana JANKOVIĆ, Department of Preventive Dentistry and Pedodontics, Study Program of Dentistry, Faculty of Medicine, Studentska 5, 73300 Foča, Bosnia and Herzegovina; svjetlanajankovic@yahoo.com 
mixed dentition is also important [6]. School age is characterized by intense shift from deciduous to permanent teeth and therefore it is important to assess the state of mouth where permanent teeth erupt. On the other hand, it is a direct indicator of how much parents care about their children's dental health. Habits that children have towards their own health have origin in their families [7]. If preventive and prophylactic methods are applied earlier success can be expected. For these reasons, the status of deciduous dentition has great importance on permanent dentition health, i.e., the first permanent molars, as the first permanent teeth that erupt in mixed dentition [5]. Epidemiological data provides insight into the spread of disease and can be used to create a preventive program which goal should be improvement of oral health measures [8].

The aim of the study was to assess the status of deciduous teeth in school children from four cities in Republika Srpska.

\section{MATERIALS AND METHODS}

The study included children from four cities in Republika Srpska (Foča, Kalinovik, Rogatica Čajniče), Bosnia and Herzegovina. The study was performed as a cross-sectional descriptive study in May 2012. Children who showed up at the Department of Preventive Dentistry and Pedodontics in Foča were examined. The examinations were conducted in accordance with criteria of the World Health Organization under artificial light using dental mirrors and probes [9]. After obtaining permission from their parents, first to fifth grade of primary school children were examined (Group I). To eliminate the bias that "patients come to dental clinic only when a tooth hurts", the study included a group of children randomly selected in all four cities. These examinations were done in a school classroom, on daylight, using the same dental instruments (Group II). For the examination of these children approval from the director and teachers was obtained.

The current study included only deciduous teeth, usually canines and molars depending on the age of a patient. Incisors in both jaws (if they were present) were not taken into account as well as the children who had less than eight deciduous teeth. The prevalence of caries was verified by Klein-Palmer system, based on which the $\mathrm{dmft}$ index of deciduous teeth was established (d-decay, $\mathrm{m}$-missing, $\mathrm{f}$-filling) as well as related indices [2].

In addition we developed a questionnaire that consisted of four questions, separately for these two groups. For the Group I, parents filled out the questionnaire, while in the Group II children responded to the questions.

Data was analyzed by descriptive statistics and using $\chi 2$-test in the software SPSS 11.5.

\section{RESULTS}

The total of 228 children, age 6-10 years (the average was 8 years (SD 0.75)) were examined (110 girls and 118 boys).
The average age for girls was 8.06 (SD 0.86) and for boys 7.98 (SD 0.81). Analysis of the data revealed no statistically significant difference in regards to gender $\left(\chi^{2}=0.687\right.$; $p>0.05$ ). The group of children who were examined at the clinic (Group I) consisted of 128 patients while the group of children examined at school (Group II) included 100 subjects (there were five in each grade). There was no statistically significant difference between these two groups $\left(\chi^{2}=0.747 ; p>0.05\right)$. Most of examined children were from Foca, the largest economic and cultural center in this area with about 25,000 inhabitants, whereas other cities have all together nearly the same number of inhabitants.

Of the total number of respondents, only $3.94 \%$ had all healthy deciduous teeth. Person caries index (pci) i.e., the prevalence rate of diseased teeth for all respondents was 96.1\%. (in Group I 95.94\%; in Group II 96.26\%). There was no statistically significant difference between these groups $\left(\chi^{2}=0.955 ; p>0.05\right)$. The average number of diseased teeth per respondent, for all examined children, the average caries index (aci) was 4.17 (in Group I 4.26; in Group II 4.08). There was no statistical significance between these two groups $\left(\chi^{2}=1.048 ; p>0.05\right)$. Of total number of respondents $10.52 \%$ had fillings in deciduous teeth. In the Group I there were $14.8 \%$ of children with fillings while in the Group II there were 5\% of such patients. There was statistically significant difference between these two groups $\left(\chi^{2}=12.341 ; \mathrm{p}<0.05\right)$.

None of deciduous teeth had fissure sealant. Children from Cajnice had no fillings in primary teeth. In the Group I, 7.9\% of children showed up at the clinic because of odontogenic pain, while $2.6 \%$ of children reported the presence of swelling in orofacial region. None of children in the Group II had these problems at the time of dental examination. Examination revealed that $12.2 \%$ of children in both groups had submucosal abscess.

The results of the survey for the Group I showed that $75.8 \%$ of children had pain in childhood of dental origin. According to the responses obtained from parents $10.1 \%$ of respondents had a swelling of odontogenic origin while $27.3 \%$ of parents noted the existence of submucosal abscess most often localized in the fornix beside the diseased tooth (Table 1). Since oral hygiene is an important part of oral health we were interested whether children had a toothbrush to maintain oral hygiene. All parents reported that their children had their own toothbrush. Based on the survey results for the Group II it was observed that $74 \%$ of children had pain of dental origin, $3 \%$ of children stated that they do not have their own toothbrush while $62 \%$ of children confirmed that parents are not supervising them to brush teeth (Table 2).

\section{DISCUSSION}

Deciduous teeth have multiple important functions: promote normal growth and development of jaws, allow chewing (which is an important prerequisite for good digestion), participate in speech and development of a clear and understandable language, keep the place for their successors and influence the aesthetic appearance 
Table 1. Distribution of answers for the Group I

Tabela 1. Raspodela odgovora ispitanika grupe I

\begin{tabular}{|l|c|c|}
\hline $\begin{array}{l}\text { Questions } \\
\text { Pitanja }\end{array}$ & $\begin{array}{c}\text { Yes } \\
\text { Da }\end{array}$ & $\begin{array}{c}\text { No } \\
\text { Ne }\end{array}$ \\
\hline $\begin{array}{l}\text { Have your child ever had a toothache? } \\
\text { Da li je vaše dete dosad boleo zub? }\end{array}$ & $75.8 \%$ & $24.2 \%$ \\
\hline $\begin{array}{l}\text { Have your child ever had a swelling because of any tooth? } \\
\text { Da li je dosad bilo otoka zbog zuba? }\end{array}$ & $10.1 \%$ & $85.3 \%$ \\
\hline $\begin{array}{l}\text { Have your child ever had a fistula above any tooth? } \\
\text { Da li je dosad bilo apscesa (fistula) iznad zuba? }\end{array}$ & $28.1 \%$ & $69.6 \%$ \\
\hline $\begin{array}{l}\text { Does your child have a toothbrush? } \\
\text { Da li dete ima četkicu za zube? }\end{array}$ & $100 \%$ & - \\
\hline
\end{tabular}

Table 2. Distribution of answers for the Group II

Tabela 2. Raspodela odgovora ispitanika grupe II

\begin{tabular}{|l|c|c|}
\hline $\begin{array}{l}\text { Questions } \\
\text { Pitanja }\end{array}$ & $\begin{array}{c}\text { Yes } \\
\text { Da }\end{array}$ & $\begin{array}{c}\text { No } \\
\text { Ne don't remember } \\
\text { Ne sećam se }\end{array}$ \\
\hline $\begin{array}{l}\text { Have you ever had a toothache? } \\
\text { Da li vas je ikada boleo zub? }\end{array}$ & $74 \%$ & $26 \%$ \\
\hline $\begin{array}{l}\text { Have you ever had a swelling because of a tooth? } \\
\text { Da li ste nekad imali otok zbog zuba? }\end{array}$ & $10 \%$ & $66 \%$ \\
\hline $\begin{array}{l}\text { Do your parents supervise your toothbrushing? } \\
\text { Da li vam roditelji peru zube ili vas kontrolišu kako ih perete? }\end{array}$ & $38 \%$ & $62 \%$ \\
\hline $\begin{array}{l}\text { Do you have a toothbrush? } \\
\text { Da li imate četkicu za zube? }\end{array}$ & $97 \%$ & $3 \%$ \\
\hline
\end{tabular}

of the face. The results of this study demonstrate that a little attention is given to their health. The important fact is that healthy deciduous teeth allow their successors to erupt in a healthy environment. The condition of deciduous dentition largely influences the state of permanent dentition $[10,11,12]$.

Only $3.94 \%$ of the children in this sample had all healthy primary teeth, which is very low. In the twentyfirst century, when medicine is that advanced, it is unacceptable that $96.1 \%$ of children, on average, had 4.17 affected teeth. There are number of preventive and prophylactic measures that can successfully accomplish this goal. We find good example of this in Scandinavian countries and developed countries. In developed countries, the prevalence of dental caries has been declining while in low-income countries it is still high [13]. Underdeveloped and developing countries, such as Bosnia and Herzegovina, and therefore Republika Srpska, are faced with high prevalence of caries in school children $[14,15]$. In a study conducted in Belgium, $26 \%$ - 44\% of seven year old children had all healthy teeth, while the average caries index was lowered from 4.1 to 2.24 through preventive and prophylactic measures [16]. Several studies conducted in India revealed different results depending on the area in which the survey was conducted. In one study, the prevalence of dental caries in mixed dentition in nine year old children was $92.11 \%$ [17]. In other study it was $67.26 \%$ in the age group of $7-9$ years [18], while in the third study in children of $8-10$ years this percentage was slightly lower, $49.23 \%$ [19]. In a study from Malaysia (2008) the prevalence of dental caries in primary teeth in respondents of 7-9 years was $93.0 \%$ and the average number of affected teeth was 6.2 [6]. Better results were obtained in a study conducted in US where $52 \%$ of children aged 6-8 years had affected teeth [11]. In contrast to these studies, children in China at age of 3-4 years had the incidence of dental caries of $83 \%$ [20]. The average number of affected deciduous teeth in Mexico was 2.85 while $73.6 \%$ of children had some $\mathrm{dmft}$ characteristics [21]. In Israel, $35.3 \%$ of children age 5 had all healthy teeth and the average number of affected teeth was 3.31 [22]. In a study conducted in Serbia the percentage of carious primary teeth in Novi Sad was $89.2 \%$ [23].

In the current study, a total of $10.52 \%$ had fillings on deciduous teeth. There were more fillings in the group of children who were brought by their parents for examination. This indirectly speaks about the importance of regular or occasional visits to the dentist. After examination each patient will be suggested best preventive or therapeutic measures. This study revealed no teeth with fissure sealants. Sealing of predisposed areas for caries (pits and fissures on the occlusal and lingual surfaces of both primary and permanent teeth, and the foramen caekum on incisors) is the most successful preventive measure for preservation of healthy teeth. It is especially recommended for patients at high risk for dental caries $[24,25]$.

From all stated it is obvious that deciduous teeth are exposed to caries without paying attention to them and there is a little interest for their restoration. There is common misconception that primary teeth should not be restored, because they will be replaced by permanent successors. It is true that primary teeth will be replaced by permanent teeth, but it is absolutely false that primary teeth do not deserve the same care as permanent teeth. In addition to microbial dental plaque and unhealthy eating 
patterns, many studies have confirmed the importance of oral hygiene on the health of both dentitions [26,27].

In the current study, $3 \%$ of children confirmed that they do not have the basic element for oral hygiene, a toothbrush. Also, high percentage of children admitted that their parents do not brush their teeth or they do not control their tooth brushing. Children of school age are not yet capable to independently brush their teeth [5]. It would therefore be necessary, depending on age and manual skills of a child, that parents brush or supervise children while brushing their teeth.

Caries complications often lead to pain, suffering, or infection, and thus decrease the quality of life in all patients, especially in children [28]. Complications are very common, as confirmed by data from the survey. Of all children, toothache had $75.8 \%$ of children, swelling had $10.1 \%$ and submucosal abscess $27.3 \%$ of respondents. Data obtained from children did not differ much from their parents' responses. Caries complications occurred in primary dentition, even $12.2 \%$ of the children had signs of chronic infection, i.e., the existence of submucosal abscess was observed during the inspection. Deciduous teeth erupt healthy and can be preserved healthy. A child that smiles without hesitation is socially and emotionally open.

\section{CONCLUSION}

Despite the fact that the Health Insurance Fund in Republika Srpska covers full cost of complete restoration of teeth for children up to 15 years old, caries prevalence in primary teeth is still high. Children cannot be blamed for very small percentage of healthy and restored teeth. The main responsibility relies primarily on parents and their health education and attitude about the importance of primary teeth preservation. Of course, there is responsibility of the entire community and local government to ensure the development and availability of public dental care in all areas.

\section{REFERENCES}

1. Beloica D, Vulović M, Gajić M, Stevanović R, Carević M, Ivanović M, et al. Dečja stomatologija. Beograd: Elit-Medica; 2000.

2. Vulović MD, Beloica D, Gajić M, Stevanović R, Ivanović M, Carević M, et al. Preventivna stomatologija. Beograd: Draslar partner; 2005.

3. USDHHS. A Report of the Surgeon General. Rockville: Department of Health and Human Services, US Public Health Service; 2000.

4. Molina FN, Irigoyen M, Castaneda CE, Sanchez HG, Bologna RE. Dental decay in choolchildren of different socioeconomic level. Rev Mex Pediatr. 2002; 69:53-6.

5. Slavković V, Stevanović R. Karijes mlečne denticije i prvog stalnog molara kod dece u nižim razredima osnovne škole. Acta medica Semendrica. 2002; 9:117-20.

6. Oo MMT, Naing L, Mani SA, Ismai AR. Dental caries experience and treatment needs in the mixed dentition in North East Malaysia. Arch Orofac Sci. 2011; 6:1-8.
7. Janjanin M. Programski zdravstveno vaspitni rad u prevenciji karijesa. Stomatološki glasnik Srbije. 2000; 47:25-7.

8. Ivanović M, Carević M, Marković D, Vulićević Z, Stevanović R, Petrović $\mathrm{V}$, et al. Protokoli u stomatologiji. Beograd: Stomatološki fakultet; 2009.

9. World Health Organization. Oral Health Surveys - Basic Methods. 4th ed. Geneva: WHO; 1997.

10. Helm S, Helm T. Correlation between caries experience in primary and permanent dentition in birth-cohorts 1950-70. Scand I Dent Res. 1990; 98:225-7.

11. Kaste LM, Selwitz RH, Oldakowski RJ, Brunelle JA, Winn DM, Brown LJ. Coronal caries in the primary and permanent dentition of children and adolescents 1-17 years of age: United States, 1988-1991. J Dent Res. 1996; 75:631-41.

12. Skeie MS, Raadal M, Strand GV, Espelid I. The relationship between caries in the primary dentition at 5 years of age and permanent dentition at 10 years of age - a longitudinal study. Int J Paediatr Dent. 2006; 16:152-60.

13. Bonecker M, Cleaton-Jones P. Trends in dental caries in Latin American and Caribbean 5-6 and 11-13-year-old children: a systematic review. Community Dent Oral Epidemiol. 2003; 31:152-7.

14. Obradović M, Dolić O. Prevalencija karijesa i faktori rizika za njegov nastanak u urbanoj i ruralnoj sredini. Stomatološki glasnik Srbije. 2008; 55:34-43.

15. Davidović B, Ivanović M, Janković S. Dental health estimation for children age twelve and fifteen. Stomatološki glasnik Srbije. 2012; 59:35-43.

16. Vanobbergen J, Martens L, Declerk D. Caries prevalence in Belgian children: a review. Int J Paediatr Dent. 2001; 11:164-70.

17. Goyal A, Gauba K, Chawla HS, Kaur M, Kapur A. Epidemiology of dental caries in Chandigarh school children and trends over the last 25 years. I Indian Soc Pedod Prev Dent. 2007; 25:115-8.

18. Grewal $H$, Verma M, Kumar A. Prevalence of dental caries and treatment needs in the rural child population of Nainital District, Uttaranchal. J Indian Soc Pedod Prev Dent. 2009; 27:224-6.

19. Dhar V, Bhatnagar M. Dental caries and treatment needs of children (6-10 years) in rural Udaipur, Rajasthan. Indian J Dent Res. 2009; 20:256-60.

20. Li Y, Wang W. Predicting caries in permanent teeth from caries in primary teeth: an eight-year cohort study. J Dent Res. 2002; 81:561-6.

21. Jose A, Eduardo C, Fernando J, Alicia A, Maupome G, Avila L. Dental caries and associated factors in Mexican schoolchildren aged 6-13 years. Acta Odontol Scand. 2005; 63:245-51.

22. Natapov L, Gordon M, Pokovsky V, Kushnir D, Kooby E, Khoury G, et al. Caries prevalence among five-year-old children examined by the school dental service in Israel in 2007. OHDMBSC. 2010; 9:25-31.

23. Blagojević D, Stojšin I. Uticaj fluorida u pijaćoj vodi na zdravlje mlečnih zuba. Med Pregl. 2004; 57:323-6.

24. Berger S, Goddon I, Chen CM, Senkel H, Hickel R, Stosser L, et al. Are pit and fissure sealants needed in children with a higher caries risk? Clin Oral Invest. 2010; 14:613-20.

25. Beauchamp J, Caufield PW, Crall J, Donly K, Feigal R, Gooch B, et al. Evidence-based clinical recommendations for the use of pit-andfissure sealants: a report of the American Dental Association Council on Scientific Affairs. J Am Dent Assoc. 2008; 139:257-68.

26. Vanobbergen J, Declerck D, Mwalili S, Martens L. The effectiveness of a 6-year oral health education programme for primary schoolchildren. Community Dent Oral Epidemiol. 2004; 32:173-82.

27. Martens L, Vanobbergen J, Leroy R, Lesaffre E, Declerck D. Variables associated with oral hygiene levels in 7-year-olds in Belgium. Community Dent Health. 2004; 21:4-10.

28. Casamassimo PS, Thikkurissy S, Edelstein BL, Maiorini E. Beyond the $\mathrm{dmft}$ : the human and economic cost of early childhood caries. I Am Dent Assoc. 2009; 140:650-7.

Received: 01/06/2012 • Accepted: 01/08/2012 


\title{
Procena stanja mlečne denticije dece uzrasta 6-10 godina
}

\author{
Svjetlana Janković1, Bojana Davidović', Mirjana Ivanović , Jelena Lečić3 , Slavoljub Tomić \\ ${ }^{1}$ Katedra za dječiju i preventivnu stomatologiju, Studijski program Stomatologija, Medicinski fakultet, Univerzitet u Istočnom \\ Sarajevu, Foča, Bosna i Hercegovina; \\ ${ }^{2}$ Klinika za preventivnu i dečju stomatologiju, Stomatološki fakultet, Univerzitet u Beogradu, Beograd, Srbija; \\ ${ }^{3}$ Katedra za paradontologiju i oralnu medicinu, Studijski program Stomatologija, Medicinski fakultet, Univerzitet u Istočnom \\ Sarajevu, Foča, Bosna i Hercegovina; \\ ${ }^{4}$ Katedra za oralnu hirurgiju, Studijski program Stomatologija, Medicinski fakultet, Univerzitet u Istočnom Sarajevu, Foča, \\ Bosna i Hercegovina
}

\begin{abstract}
KRATAK SADRŽAJ
Uvod Nicanje mlečnih zuba najčešće izaziva radost svakog roditelja. Međutim, nakon „kratkotrajne euforije“ ovi zubi kod većine dece postaju uzrok bola, otoka, infekcije i dodatnih komplikacija. Cilj ovog rada bio je da se proceni stanje zdravlja mlečnih zuba dece školskog uzrasta.

Materijal i metode rada $U$ istraživanje su uključena deca uzrasta 6-10 godina iz četiri grada u Republici Srpskoj. Ispitanici su svrstani u dve grupe: grupa I je obuhvatila one koji su se svojevoljno javili na pregled u stomatološku kliniku, a grupa II one koji su izabrani metodom slučajnog izbora u školama. Pregled je urađen stomatološkom sondom i ogledalom. Potvrda karijesa izvršena je prema Klajn-Palmerovom (Klein-Palmer) sistemu kep (k - karijesni zub; e - ekstrahovan zub; p - plombiran zub) i njemu srodnim indeksima - karijes indeks osoba (kio) i prosečni karijes indeks (kip). Kao dodatak istraživanju korišćena je anketa.

Rezultati Pregledano je ukupno 228 ispitanika. Ukupna vrednost kio bila je 96,1\%. U proseku, svako dete je imalo 4,17 obolelih mlečnih zuba (kip), dok je 10,52\% dece imalo ispune na mlečnim zubima. Ni kod jednog deteta nije bilo zalivenih fisura na mlečnim zubima. Pregledom je kod 12,2\% dece uočen submukozni apsces (parulis) u usnoj duplji. Iz ankete je ustanovljeno da $3 \%$ dece uopšte nema četkicu za zube.

Zaključak Rasprostranjenost karijesa na mlečnim zubima je visoka i pored činjenice da Fond zdravstvenog osiguranja deci do 15 godina u Republici Srpskoj snosi celokupne troškove sanacije zuba. Za mali procenat zdravih, kao i saniranih zuba odgovornost treba da preuzmu roditelji, ali i celokupna društvena zajednica, koja treba da obezbedi razvijenost i dostupnost zdravstvene stomatološke zaštite na svim područjima.
\end{abstract}

Ključne reči: mlečni zubi; karijes; kep; deca

\section{UVOD}

Mlečni zubi (dentes lactales, dentes decidui, dentes caduci) se od stalnih zuba razlikuju po morfološkim i histološkim odlikama. Od morfoloških razlika najizraženija promena je u broju, obliku, veličini i boji zuba. Posebno obeležje je postojanje gleđno-dentinskog bedema, koji se nalazi na vestibularnoj površini molara i koji štiti gingivu od impakcije hrane. Svi su manji od stalnih zuba, a gleđ im retko prelazi prosečnu debljinu od $1 \mathrm{~mm}$. Zbog slabije mineralizacije, boja zuba je mlečnobela, dok je na sečivnim ivicama često izražena atricija [1]. Kada su histološke odlike u pitanju, najizraženija promena je u mineralizaciji zuba. Deo gleđi stvoren pre rođenja je bolje mineralizovan. Broj dentinskih kanalića je manji, ali su oni širi i nepravilnijeg su oblika. Cement je tanak i slabo mineralizovan, dok je komora pulpe voluminozna is izraženim rogovima. Raspored Šarpejevih (Sharpey) vlakana je nepravilniji, a njihov broj takođe manji u odnosu na stalne zube [1].

Prvi mlečni zubi se najčešće pojavljuju između šestog i osmog meseca po rođenju, dok se celokupna mlečna denticija formira oko treće godine. S nicanjem zuba dolazi do promene oralne mikroflore, jer se pojavljuju mikroorganizmi kojima su zubi primarno stanište (Streptococcus sanguis, Streptococcus mutans i Actinomyces viscosus) [2]. Danas je karijes najrasprostranjenije hronično oboljenje kod dece [3], koje je zbog svoje učestalosti postalo opštezdravstveni problem [4]. Nova saznanja iz oblasti biohemije, mikrobiologije, elektronske mikroskopije i drugih nauka dovela su do današnjeg stava da je karijes infektivna bolest koja je u direktnoj zavisnosti od ishrane [5].
Najveći broj studija i nacionalnih istraživanja o rasprostranjenosti karijesa, koje su izvedene na različitim geografskim područjima i u različitim zemljama, obuhvatio je decu uzrasta od šest, dvanaest i petnaest godina. Međutim, ništa manje važni nisu ni podaci o stanju zdravlja zuba u mešovitoj denticiji [6]. Školski uzrast odlikuje intenzivna smena mlečnih i stalnih zuba, pa je stoga važno utvrditi i kakvo je stanje usne duplje gde niču stalni zubi. S druge strane, to je direktni pokazatelj koliko roditelji vode računa o zdravlju zuba svoje dece. Navike koje deca imaju u pogledu sopstvenog zdravlja duboko su ukorenjene u porodici [7]. Što se ranije počne s primenom preventivno-profilaktičkih metoda, uspeh će biti bolji. Zbog navedenih razloga, stanje mlečne denticije dobija veći značaj u odnosu na zdravlje stalne denticije, odnosno prvog stalnog molara, kao prvog stalnog zuba u mešovitoj denticiji [5]. Epidemiološki podaci omogućavaju uvid u rasprostranjenost oboljenja i mogu se iskoristiti za izradu programa čiji je cilj unapređenje oralnozdravstvenih mera [8].

Cilj ovog rada bio je da se proceni stanje zdravlja mlečnih zuba dece školskog uzrasta u četiri grada u Republici Srpskoj.

\section{MATERIJAL I METODE RADA}

U istraživanje su uključena deca iz četiri grada u Republici Srpskoj (Foča, Kalinovik, Rogatica, Čajniče), u Bosni i Hercegovini. Ispitivanje je urađeno kao deskriptivna studija preseka u maju 2012. godine. Deci koja su se iz bilo kojeg razloga javila na Kliniku za dječiju i preventivnu stomatologiju u Foči urađen je stomatološki pregled. Pregledi su obavljeni u skladu s kriterijumima 
Svetske zdravstvene organizacije pri veštačkom osvetljenju i uz korišćenje stomatološke sonde i ogledala [9]. Pregledana su deca od prvog do petog razreda osnovne škole, uz odobrenje roditelja koji su ih i doveli na pregled (Grupa I). Da bi eliminisali mogućnost i tvrdnju da „pacijenti dolaze u stomatološku ordinaciju samo kada ih zaboli zub", u istraživanje je uključena i grupa dece koja je metodom slučajnog uzorka pregledana $\mathrm{u}$ svakom pomenutom gradu. Ovi pregledi su urađeni u školskoj učionici, na dnevnom svetlu i uz korišćenje istih stomatoloških instrumenata (Grupa II). Za pregled ove dece dobijena je saglasnost direktora i pedagoga škole.

Studijom je obuhvaćen pregled samo mlečnih zuba, i to očnjaka i kutnjaka, što je zavisilo od uzrasta deteta. Sekutići nisu uzimani u obzir, kao ni deca koja su imala manje od osam mlečnih zuba. Rasprostranjenost karijesa je potvrđena Klajn-Palmerovim (Klein-Palmer) sistemom, na osnovu kojeg su utvrđene vrednosti indeksa kep za mlečne zube (k - karijesni zub; e - ekstrahovan zub; p - plombiran zub) i njemu srodnim indeksima [2].

Kao dodatak istraživanju načinjen je i anketni upitnik sa četiri pitanja, posebno za obe grupe. Za decu grupe I roditelji su popunili anketni upitnik, dok su za grupu II deca odgovarala na postavljena pitanja.

Dobijeni podaci su statistički obrađeni u programu SPSS, ver. 11.5. Podaci su analizirani metodama deskriptivne statistike i $\chi^{2}$-testom.

\section{REZULTATI}

Ukupno je pregledano 228 dece uzrasta 6-10 godina (u proseku $8 \pm 0,75$ godina). U istraživanju je učestvovalo 110 devojčica (prosečnog uzrasta od $8,06 \pm 0,86$ godina) i 118 dečaka (prosečnog uzrasta od $7,98 \pm 0,81$ godinu). Analizom podataka utvrđeno je da ne postoji statistički značajna razlika kada je pol u pitanju $\left(\chi^{2}=0,687 ; p>0,05\right)$. Na klinici je pregledano 128 dece (grupa I), a u školi (grupa II) 100 dece (u svakom razredu po pet učenika). Ni između ovih grupa nije utvrđena statistički značajna razlika $\left(\chi^{2}=0,747 ; p>0,05\right)$. Najviše je pregledano dece iz Foče, koja je ujedno na ovom području najveći privredni i kulturni centar, s oko 25.000 stanovnika, dok ostali gradovi zajedno imaju približno toliko.

Od ukupnog broja pregledanih ispitanika samo 3,94\% dece imalo je potpuno zdrave mlečne zube. Vrednost karijes indeksa osoba (kio), tj. ukupna stopa rasprostranjenosti obolelih zuba za sve ispitanike, bila je 96,1\% (u grupi I 95,94\%; u grupi II $96,26 \%)$. U pogledu ovog parametra, između grupa nije bilo statističke značajne razlike $\left(\chi^{2}=0,955 ; \mathrm{p}>0,05\right)$. Prosečan broj obolelih zuba po ispitaniku za svu pregledanu decu, tj. prosečan karijes indeks (kip), bio je 4,17 (u grupi I 4,26; u grupi II 4,08). Između grupa nije bilo statistički značajne razlike ni u pogledu ovog parametra $\left(\chi^{2}=1,048 ; p>0,05\right)$. U našoj studiji ukupno $10,52 \%$ ispitanika je imalo ispune na mlečnim zubima. U grupi I bilo je 14,8\% dece s ispunima, a u grupi II 5\%. Između dve grupe ispitanika uočena je statistički značajna razlika $\left(\chi^{2}=12,341\right.$; $\mathrm{p}<0,05)$.

Ni na jednom mlečnom zubu nije ustanovljen zalivač fisura. Deca iz Čajniča nisu imala ispune na mlečnim zubima. U grupi I 7,9\% dece na pregled se javilo zbog bola dentogenog porekla, dok je 2,6\% dece došlo zbog otoka u orofacijalnoj regiji. Nijedno dete iz grupe II u trenutku stomatološkog pregleda nije imalo pomenute promene. Pregledom je kod 12,2\% dece iz obe grupe utvrđen submukozni apsces u ustima.

Rezultati ankete za grupu I pokazuju da je 75,8\% dece u detinjstvu imalo bolove čiji su uzrok bili zubi. Prema odgovorima roditelja, 10,1\% dece imalo je otok koji je bio dentogenog porekla, dok je $27,3 \%$ roditelja primetilo submukozni apsces (parulis), koji je najčešće bio lokalizovan u forniksu, uz oboleli zub (Tabela 1). Kako je higijena zuba važan segment oralnog zdravlja, zanimalo nas je da li deca imaju neophodna sredstva za održavanje higijene usta i zuba. Svi roditelji su izjavili da njihova deca imaju četkicu za zube. Na osnovu rezultata ankete, $74 \%$ dece iz grupe II imalo je bolove čiji su uzročnici bili zubi. $\mathrm{U}$ ovom istraživanju $3 \%$ dece je izjavilo da nema četkicu za zube, dok je $62 \%$ dece odgovorilo da im roditelji ne peru zube (Tabela 2).

\section{DISKUSIJA}

Mlečni zubi imaju višestruko važnu funkciju: podstiču normalan rast i razvoj vilica, omogućavaju žvakanje (što je značajan preduslov za dobru probavu), učestvuju u stvaranju glasova, te razvoju jasnog i razumljivog govora, čuvaju mesto za svoje naslednike i utiču na estetski izgled lica. Rezultati ove studije pokazuju da se u dovoljnoj meri ne posvećuje pažnja njihovom zdravlju. Važna činjenica je da zdravi mlečni zubi omogućavaju stalnim zubima da niknu u zdravom okruženju. Stanje mlečne denticije u velikoj meri se odražava na stanje zuba stalne denticije $[10,11,12]$.

Procenat dece sa svim zdravim mlečnim zubima u našem istraživanju $(3,94 \%)$ veoma je nizak. U 21. veku, kada je medicina toliko napredovala, nedopustivo je da $96,1 \%$ dece nema potpuno zdravu mlečnu denticiju, odnosno da u proseku imaju po 4,17 obolelih zuba. Danas postoji veliki broj preventivnih i profilaktičkih mera kojima se uspešno može ostvariti taj cilj. Primer za to su skandinavske i ostale razvijene zemlje. U ovim zemljama prevalencija karijesa se smanjuje, dok se u zemljama u razvoju ova pojava odigrava sporo [13]. Nerazvijene i zemlje u razvoju, kao što je Bosna i Hercegovina, a samim tim i Republika Srpska, i dalje su suočene s visokom učestalošću karijesa kod dece školskog uzrasta $[14,15]$. U Belgiji 26-44\% sedmogodišnjaka ima sve zdrave zube, dok se vrednost prosečnog karijes indeksa, zahvaljujući preventivno-profilaktičkim merama, sa 4,1 smanjila na na 2,24 [16]. U Indiji je rađeno nekoliko studija i podaci su različiti, zavisno od područja u kojem je vršeno istraživanje. U jednoj studiji na devetogodišnjacima prevalencija karijesa u mešovitoj denticiji je 92,11\% [17], u drugoj, kod dece uzrasta 7-9 godina, 67,26\% [18], dok je u trećoj studiji, koja je obuhvatila decu uzrasta $8-10$ godina, taj procenat nešto niži $49,23 \%$ [19]. U studiji iz Malezije koja je rađena 2008. godine na ispitanicima uzrasta 7-9 godina prevalencija karijesa na mlečnim zubima je 93,0\%, a prosečan broj obolelih mlečnih zuba 6,2 [6]. Mnogo bolji podaci su prikazani u američkoj studiji gde je $52 \%$ dece uzrasta 6-8 godina imalo obolele zube [11].Za razliku od Amerike, 83\% dece u Kini u uzrastu od tri-četiri godine već ima karijes [20]. Ispitivanje vršeno u Meksiku pokazuje da je prosečan broj obolelih mlečnih zuba 2,85, dok ukupno 73,6\% dece ima neko od obeležja kep [21]. U Izraelu je 35,3\% petogodišnjaka bez karijesa, a u proseku imaju po 3,31 oboleli zub [22] 
U studiji koja je rađena u Srbiji procent karijesnih mlečnih zuba kod dece u Novom Sadu bio je 89,2\% [23].

U našoj studiji ukupno 10,52\% dece imalo je ispune na mlečnim zubima. Više je bilo ispuna u grupi dece koju su roditelji doveli na pregled. To indirektno govori o važnosti redovnih ili povremenih poseta stomatologu. Nakon pregleda svakom pacijentu će biti predložene najbolje preventivne ili terapijske mere. U ovoj studiji nije uočen nijedan zub koji je na svojim jamicama ili fisurama imao zalivač fisura. Zalivanjem predilekcionih mesta za karijes (jamice i fisure na okluzalnim i oralnim površinama kako mlečnih, tako i stalnih zuba, te foramen cekum na sekutićima) najuspešnija je mera prevencije očuvanja zdravlja zuba. Posebno se preporučuje kod osoba s visokim rizikom za razvoj karijesa [24, 25].

Iz svega navedenog vidi se da, osim što obolevaju, mlečnim zubima se ne poklanja dovoljna pažnja,jer se u malom procentu saniraju. Čini se da je to zbog činjenice da je i dalje uvreženo mišljenje da mlečne zube ne treba čuvati jer će ih zameniti stalni zubi. Tačno je da će mlečne zube zameniti stalni, međutim, potpuno je netačno da mlečni zubi ne zaslužuju jednaku brigu kao i stalni zubi. Pored mikroorganizama dentalnog plaka i nezdravih navika u ishrani, mnoge studije govore o važnosti i uticaju oralne higijene na zdravlje zuba obe denticije [26,27].

U našoj studiji čak $3 \%$ dece je izjavilo da nema jedan od osnovnih elemenata pribora za održavanje oralne higijene četkicu za zube. Takođe je veliki procenat dece priznao da im roditelji ne peru zube ili ih ne kontrolišu u obavljanju ove važne preventivne aktivnosti. Dete školskog uzrasta još nije spretno da samo pere zube [5], te bi zbog toga bilo neophodno da im, zavisno od uzrasta i manuelnih sposobnosti, roditelji peru zube ili proveravaju kako su ih oprali.

Komplikacije karijesa često dovode do bola, patnje ili infekcije, čime se umanjuje kvalitet života pacijenata svih uzrasta, a posebno dece [28]. Da su komplikacije i te kako česte potvrđuju rezultati ankete. $\mathrm{U}$ detinjstvu je zubobolju imalo 75,8\% dece, otok $10,1 \%$, a submukozni apsces $27,3 \%$ ispitanika. Podaci koji su dobijeni od dece ne odstupaju mnogo od odgovora njihovih roditelja. Dokaz da se komplikacije karijesa javljaju još u mlečnoj denticiji je i činjenica da je ukupno 12,2\% dece imalo znake hronične infekcije (submukozni apsces), koji su uočeni tokom samog pregleda. Zubi niču zdravi i mogu ostati zdravi. Tome treba težiti, jer dete koje se bez ustezanja osmehuje mnogo je društvenije i emocionalno slobodnije.

\section{ZAKLJUČAK}

I pored činjenice da Fond zdravstvenog osiguranja deci do 15 godina u Republici Srpskoj snosi celokupne troškove sanacije zuba, rasprostranjenost karijesa na mlečnim zubima je zaista visoka. Za izrazito mali procenat zdravih i saniranih zuba ne mogu se kriviti deca. Odgovornost treba da preuzmu, pre svih, roditelji, jer ne treba zanemariti veliki uticaj zdravstvene prosvećenosti, odnosno njihovog stava u vezi sa značajem lečenja i očuvanja mlečnih zuba. Naravno, odgovornost je i na celokupnoj društvenoj zajednici i lokalnoj samoupravi, koje treba da obezbede razvijenost i dostupnost opštezdravstvene stomatološke zaštite na svim područjima. 